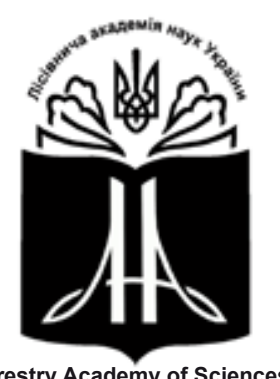

Forestry Academy of Science of Ukraine

Наукові праці Лісівничої академії наук України Proceedings of the Forestry Academy of Sciences of Ukraine

http://fasu.nltu.edu.ua https://doi.org/10.15421/411822

Article received 2018.05.18

Article accepted 2018.10.25
ISSN 1991-606X print

ISSN 2616-5015 online

(a) $\triangle$ Correspondence author

Nadiia Oleksiichenko nadiaolex@ukr.net

General Rodimtsev st., 19, Kyiv, 03041, Ukraine

УДК 712.253:502

\title{
Особливості впливу середовища на оцінювання естетичних якостей паркових пейзажів: теоретичні та прикладні аспекти
}

\author{
Н.О. Олексійченко ${ }^{1}$, Н. В. Гатальська²
}

Наведено спектр досліджень естетичного оцінювання ландшафту із залученням респондентів (42 особи), які здійснено упродовж 2017-2018 рр. безпосередньо в парковому середовищі та із застосуванням фотографій. Враховуючи різні методологічні підходи та за результатами порівняльного аналізу особливостей сприйняття пейзажів паркового середовища, виявлено взаємозв'язки між естетичною оцінкою паркового ландшафту та ознаками, які впливають на ї̈ формування.

За результатами узагальнень теоретичних та практичних наукових робіт виявлено принцииову різницю у методології досліджень естетики паркових ландшафтів із залученням респондентів. Ключовим методологічним питанням дослідження естетики паркового середовища є визначення способу проведення досліджень - натурний, або заміщення.

Встановлено, щзо за умов оцінювання паркового середовищза безпосередньо в парку оцінка знижується порівняно з фотографіями. За аналізом частоти згадувань ознак та характеристик, які позитивно впливають на естетику пейзажів Марї̈нского парку, визначено їх подібність упродовж різних сезонів за умов проведення оцінювання в середовищі та суттєві відмінності під час застосування фото. Отримані результати можуть бути свідченням подібності сприйняття паркового середовища упродовж року безпосередньо в парку. Поряд із тим, виявлено суттєві відмінності у частоті згадувань низки ознак у межах кожного сезону за умов застосування різних способів досліджень. Незважсаючи на суттєву різницю у частоті згадувань ознак паркового середовища за різних умов та способів проведення досліджень, встановлено, шьо сила впливу конкретної ознаки на естетичні якості пейзажів не визначає ї̈ факторну вагу в оцінці, однак пов'язана із нею. Окрім того, виявлено ознаки, вплив яких на естетичну оцінку паркового середовища є суттєвим.

Застосування фотографій є доиільним для визначення сприйняття колориту та образно-символічної структури пейзажів паркового середовища відвідувачами, а оцінювання впливу насаджень та архітектурних компонентів на естетичні якості пейзажів варто проводити безпосередньо в парку. Оцінювання задоволеності відвідувачів парку станом його компонентів можна здійснювати із застосуванням фотографій, або безпосередньо в парку за комфортних для людини умов (весняно-літній період).

Ключові слова: сприйняття паркових пейзажів; методологія оцінювання ландшафту; сезонна динаміка; кореляційний аналіз.

\footnotetext{
Олексійченко Надія Олександрівна - академік Лісівничої академії наук України, доктор сільськогосподарських наук, професор кафедри ландшафтної архітектури та фітодизайну. Національний університет біоресурсів і природокористування України, вул. Генерала Родімцева, 19, м. Київ, 03041, Україна. Тел.: 044-227-82-96, +38-098-330-22-78. E-mail: nadiaolex@ukr.net

2 Гатальська Надія Вікторівна - кандидат сільськогосподарських наук, доцент кафедри ландшафтної архітектури та фітодизайну. Національний університет біоресурсів і природокористування України, вул. Генерала Родімцева, 19, м. Київ, 03041, Україна. Тел.: 044227-82-96,+38-067-728-69-20. E-mail: gatalska@ukr.net
} 
Вступ. Посилення процесу урбанізації по всьому світу має серйозні наслідки для навколишнього середовища, а також біорізноманіття планети. Перспективним інструментом вирішення деяких проблем, пов'язаних з урбанізацією (забруднення навколишнього середовища, покращення мікроклімату), є міські парки, сталий розвиток яких можна вважати показником життєздатності урбосередовища загалом (Farahani \& Maller, 2018). Окрім того, постійно зростаючий процес урбанізації в усьому світі матиме великі екологічні наслідки, а також впливатиме на здоров'я та добробут містян (Kabisch, Qureshi \& Haase, 2015, Lin et al., 2014).

Отже, в контексті раціонального природокористування, існує потреба в адаптації наявних паркових ландшафтів до сучасних умов, проте через недостатність системних знань 3 естетики паркового середовища - методів іiї дослідження, відбувається гальмування адаптаційних процесів та деградація як природних, так і штучно створених паркових ландшафтів. Разом із тим, упродовж останніх років спостерігається значна увага учених різних галузей до естетики навколишнього середовища, що сприяє розширенню спектра досліджень естетичної оцінки ландшафту.

Насамперед розвиток естетики ландшафту спрямований на залучення респондентів під час оцінювання естетичних якостей пейзажів. Варто зазначити, що увага до дослідження сприйняття користувачів міських ландшафтних об'єктів почалася лише упродовж останнього десятиліття, що може бути свідченням проблеми формування (або реконструкціï) міських парків без урахування думки містян (Farahani \& Maller, 2018). Окрім того, актуалізація питання залучення громадськості до оцінювання естетичних якостей паркового середовища зумовлена низкою факторів, серед яких закріплення міжнародними нормативними документами доцільності дослідження ландшафту через призму сприйняття людиною та паралельний розвиток суб'єктно орієнтовних підходів вивчення естетики, а саме фокусування уваги вчених на людині як суб'єкті сприйняття.

Поряд із розширенням спектра досліджень естетичного оцінювання ландшафту із залученням респондентів, питання методів та матеріалів дослідження $є$ дискусійним у джерелах наукової літератури. До основних питань дискусії можна віднести вибір способу проведення дослідження - натурного, або заміщення.

Застосування натурного способу дослідження естетичних якостей ландшафту передбачає знаходження суб'єкта (людини) в середовищі об'єкта в момент його сприйняття та оцінювання. У такому випадку переважає чуттєве сприйняття та емоційна оцінка за рахунок мультисенсорності сприйняття середовища (Osychenko, 2015). За умов використання способу заміщення об'єкт замінюється моделлю, у ролі котрої можуть виступати плани, карти, супутникові зйомки, фотографії, тривимірні моделі тощо. За умов використання моделей пере- важає візуальне сприйняття та раціональна оцінка (Dramstad et al., 2006, Osychenko, 2015). Важливими в цьому контексті $€$ показники мінливості, які $€$ специфічним аспектом дослідження ландшафтних угруповань та включають сезонні та погодні зміни, які не лише впливають на пейзаж, а й на суб'єкт його сприйняття (за умови його знаходження в середовищі) та можуть суттєво впливати на результати естетичного сприйняття ландшафту. 3 огляду на це існує думка (Kaplan \& Kaplan, 1989), що методи виявлення естетичних преференцій, які мають відсторонений характер, є обгрунтованішими. Водночас сучасні дослідники дотримуються погляду, що сприйняття людиною паркового середовища включає візуальний аспект, з одного боку, і комфорт 3 емоціями - з іншого, який залежить від фізіологічних впливів паркового простору, таких як клімат, масштаб і функція. Проте візуальна якість простору ефективніша для людської психології (Gungor \& Polat, 2018).

Аналіз джерел наукової літератури свідчить про широке використання різного роду замінників (моделей) для аналізу естетичної привабливості ландшафтів - фотографій (Polat \& Akay, 2015, Osychenko, 2014, 2015, Yilmaz, Özgüner, \& Mumcu, 2018), супутникової зйомки та карт (Dramstad et al., 2006), 3-D моделей (Sang et al., 2008). Поряд із тим, Dramstad et al. (2006), Polat \& Akay (2015) зауважують на наявності критики використання фотографій під час дослідження естетичних переваг респондентів, оскільки вони не можуть повністю відобразити та описати реальні пейзажі. Окрім того, незважаючи на суттєвий вплив сезонної динаміки рослин на формування образу пейзажу, дослідження, що звертають увагу саме на мінливість рослин упродовж вегетаційного періоду, а також іх сприйняття людиною, є досить обмеженими. Зокрема, Thorpert \& Nielsen (2014) вивчали взаємозв'язок між видовим різноманіттям рослинного угруповання, мінливістю кольорової гами, що пов'язана із сезонною динамікою насаджень і позитивною оцінкою пейзажу. Варто зауважити, що дослідження проводили безпосередньо в середовищі, а не з використанням фото, що також рідко трапляється за умов залучення респондентів.

Отже, 3 погляду методичних аспектів основна проблема полягає у відсутності сучасних досліджень естетики паркового середовища, проведених безпосередньо у середовищі упродовж різних сезонів.

Об'єкти та методика досліджень. Об'єкт дослідження - сприйняття естетичних якостей паркових пейзажів. Предмет дослідження - особливості впливу середовища на сприйняття естетичних якостей паркових пейзажів.

Мета дослідження - проаналізувати особливості впливу середовища на сприйняття паркових пейзажів Маріїнського парку з урахуванням їх сезонної мінливості.

Методологічною основою дослідження є парадигма естетичних уподобань (Osychenko, 2015), а також психофізична парадигма (Zube et al., 1982), 
в якій естетичні якості об'єктів і закономірності сприйняття визначаються за результатами опитування та оцінювання об'єкта із залученням респондентів. Дослідження базується на роботах Thorpert \& Nielsen (2014), Dupont et al. (2014), Hofmann et al. (2012), проте має суттєві відмінності, до яких передусім належить порівняльний аналіз особливостей сприйняття пейзажів паркового середовища з використанням різних способів проведення досліджень, а також надання можливості респондентам самостійно визначати чинники, що впливають на їх оцінку, замість використання семантичних диференційних шкал.

Для дослідження було залучено 42 особи, більшість 3 яких - молоді люди. Зокрема, 29 осіб є студентами Національного університету біоресурсів і природокористування України, які навчаються за спеціальністю «Садово-паркове господарство» (вік
18-25 роки), а 12 - респонденти різного фаху та віку, серед яких 8 осіб - віком 25-40 років, 5 - 55-60 років. Серед респондентів - 7 чоловіків та 35 жінок. Усі респонденти є громадянами України.

Характеристика дослідного об 'єкта. Дослідним об'єктом обрано парк-пам'ятку садово-паркового мистецтва загальнодержавного значення Маріїнський парк, розміщений у центральній історичний частині м. Києва. У межах парку визначено 26 локацій для оцінювання пейзажів (рис. 1), які представлені на фотографіях загальною кількістю 63 екземпляри.

Добір локацій та фотографій виконували відповідно до загальноприйнятих методик проведення таких досліджень (Daniel \& Boster (1976), зокрема використаних у роботах Sang et al. (2008), Hofmann et al. (2012), Polat \& Akay (2015), Gungor $\&$ Polat (2018).

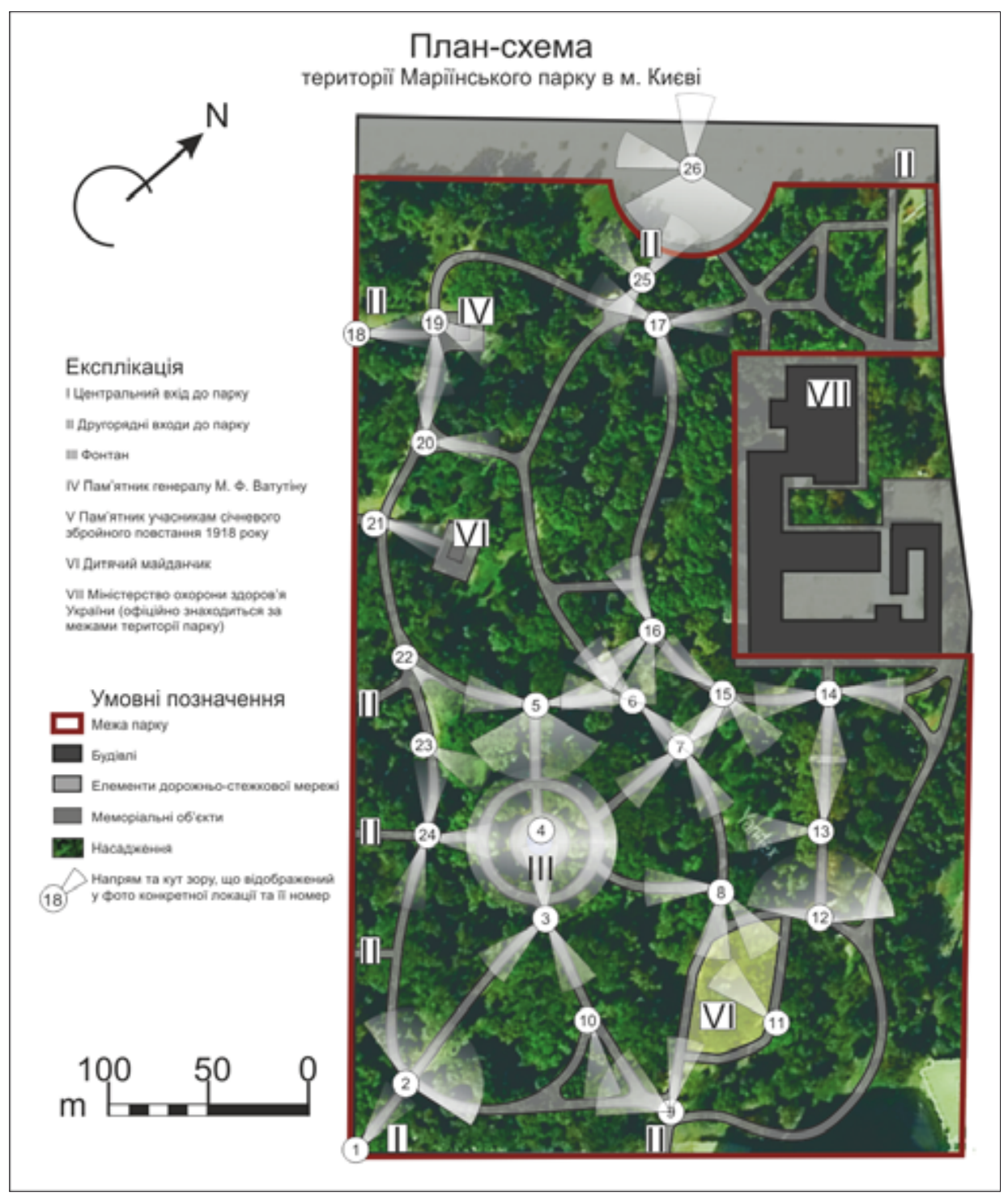

Рис. 1. План-схема розташування локацій на території Маріїнського парку, які використано для оцінювання естетичної привабливості паркового середовища, та кути зору, що відображені на фотографіях

Фотозйомка та порядок проведення дослідження. Оскільки дослідження передбачає визначення особливостей сприйняття паркових пейзажів упро- довж року, головним чином тих, що характеризують сезонні зміни, час проведення визначали відповідно до цієї вимоги. Зокрема, фотографування 
паркових пейзажів здійснювали 31.08.2017 р. (для ілюстрації літніх особливостей паркового середовища), 05.10.2017 р. (осінніх), 03.12.2017 р. (зимових) та 22.04.2018 р. (весняних) від 13:00 до 16:00 ранку із включенням людського та інших мінливих факторів до фотографій. Для фотозйомки використовували напівпрофесійну цифрову камеру 3 роздільною здатністю 20,1 мільйонів пікселів, об'єктивом з 26-разовим оптичним збільшенням та режимом панорамної зйомки. Кут більшості фотографій (59) становив 30о. Чотири фотографії було знято як 3-фазові панорами так, що вони відображали всі характеристики панорамних точок огляду. Фотографії видруковано на форматі 10×15 (папір матовий), а панорамні - $10 \times 29$.

Оцінювання паркових пейзажів безпосередньо в середовищі проводили чотири рази на рік - за різних 3 погляду комфортності для людини умов, які найчастіше проявляються в літній та весняний періоди та за умов, що можуть погіршувати комфорт внаслідок зниження температури, наявності поривів вітру, підвищення вологості (характерно для осені та зими).

3 огляду на мету дослідження, а також низку об'єктивних та суб'єктивних факторів перше оцінювання (основною вимогою якою є проведення дослідження за комфортних для людини погодних умов та колориту, характерного літнім пейзажам) проводили 21 вересня 2017 р. упродовж 13-16 год, температура повітря становила $+24^{\circ} \mathrm{C}$, відносна вологість змінювалася упродовж оцінювання від 53 до $45 \%$, сила вітру - 2 м/с східного напряму, тиск 742 мм, сонячно. Оцінювання осінніх пейзажів здійснювали 9 жовтня 2017 р. упродовж 13-16 год в умовах, що суттєво відрізняються - температура повітря становила $+10^{\circ} \mathrm{C}$, відносна вологість змінювалася упродовж оцінювання від 83 до $59 \%$, сила вітру становила $4-5 \mathrm{~m} / \mathrm{c}$ північно-західного та західного напрямів, тиск - 740 мм, хмарно, що своєю чергою $\epsilon$ типово для так званої «золотої осені». Зимові пейзажі безпосередньо в середовищі оцінювали 7 грудня 2017 р. упродовж 13-16 год. Температура повітря становила $+1{ }^{\circ} \mathrm{C}$, відносна вологість змінювалася упродовж оцінювання від $9 \%$, сила вітру становила до $1 \mathrm{~m} / \mathrm{c}$ південного напряму, тиск - 744 мм, мокрий сніг. Дослідження естетичної привабливості весняних пейзажів проводили 26.04.2018 р. за умов сонячної із змінною хмарністю погоди та температури повітря $+21{ }^{\circ} \mathrm{C}$, вологість $38 \%$, переважали вітри західного напряму $5 \mathrm{~m} / \mathrm{c}$. Оцінювання пейзажів у середовищі здійснювали після оцінювання респондентами пейзажів за фотографіями.

Анкетування та оброблення результатів. Методи визначення естетичних преференцій респондентів умовно можна розділити на дві групи. В основі першої лежить порівняльний аналіз естетичної оцінки пейзажу, отриманої за результатами опитування респондентів та параметрів компонентів ландшафту. При цьому параметризацію компонентів проводили експерти відповідно до мети дослідження, а у ролі моделей використовували фотогра- фії (зокрема і панорамні (Polat \& Akay, 2015, Gungor \& Polat, 2018, Yilmaz, Özgüner, \& Mumcu, 2018).

Другий метод базується на використанні семантичного диференціалу, розробленого Charles E. Osgood у 1952 р., та передбачає використання вербальних антонімів для визначення «загальноландшафтної» емоційної реакції респондента на певний пейзаж (Hofmann et al., 2012).

Для власних досліджень було використано обидва наведені методи, однак для виконання поставлених завдань параметризація компонентів паркового середовища експертами не проводилася. Натомість респонденту пропонували самостійно обгрунтувати ознаки пейзажу, які $\epsilon$ позитивними та підвищують його естетику, або знижують iii і можуть бути визначені як негативні. До ознак могли бути включені як матеріальні компоненти ландшафту, так і асоціативні поняття та відчуття, які потрібно було зазначити у відповідній графі навпроти номера фотографії (спосіб заміщення), або локації (за умов проведення оцінювання у середовищі) після оцінки конкретного пейзажу за 10-бальною шкалою, де 10 - найвищий бал. За основу було взято методику, використану Osychenko (2015) для визначення естетичних уподобань міського середовища.

Аналіз результатів передбачав розподіл наведених респондентами ознак пейзажів на три категорії (табл. 1), розміщені в електронній таблиці Excel 3 паралельним підрахунком середніх балів кожного окремого пейзажу, після чого вираховували частоту згадування певної ознаки респондентами у негативному та позитивному контекстах.

Для порівняльного аналізу середніх балів, між оцінкою, наданою пейзажам за фото та у середовищі, використовували середньоарифметичні значення фотографій, що відповідають одній локації. Для аналізу вихідних даних використано статистичні методи теорії ймовірності. Зокрема, кореляційний аналіз Пірсона було використано для визначення зв'язків між середнім показником візуальної якості кожної фотографії (та локації) та частотою згадування респондентами, а також взаємозалежність ознак між собою.

Результати дослідження. У ході аналізу середніх балів, наданих респондентами парковим пейзажам, базуючись на фотоматеріалах та результатах досліджень у середовищі виявлено зниження оцінки, отриманої в другому випадку в межах більшості локацій та залежить від сезону (рис. 2). Зокрема, середній бал, яким оцінено паркове середовище за фотографіями навесні - 6,2, влітку $-7,9$, восени 7,5 , взимку $-6,8$, в середовищі $-6,3$, а восени $-7,3$ 5,9 та 6,7 відповідно. Середньорічний бал за умов оцінювання фотографій $-7,1$, а безпосередньо в парковому середовищі - 6,5. Отже, найвищим балом оцінені літні пейзажі незалежно від способу проведення дослідження.

Для визначення взаємозв'язку результатів оцінки естетики паркового середовища за різних способів дослідження знайдено кореляційні зв'язки 
між балами, які були надані респондентами пейзажам за фотографіями та безпосередньо на території Маріїнського парку та виявлено суттєву різницю упродовж різних сезонів - значний кореляційний зв'язок між середнім балом фотографій і локацій у середовищі у весняний та літній періоди $-0,677$ та 0,539 відповідно, помірний $(0,366)$ - навесні та слабкий $(0,159)$ - восени.

Таблиия 1

\section{Групи ознак, зауважені в різному контексті респондентами та виділені за результатами} опрацювання анкет

\begin{tabular}{|c|c|c|}
\hline Категорія & Ознаки & Компоненти та характеристики \\
\hline \multirow{4}{*}{$\begin{array}{l}\text { Композиційні ознаки } \\
\text { паркового простору }\end{array}$} & $\begin{array}{c}\text { Естетичні якості об’ємних } \\
\text { компонентів }\end{array}$ & $\begin{array}{c}\text { Насадження } \\
\text { Архітектурні елементи } \\
\text { Рельєф } \\
\text { Компоненти запозичених пейзажів }\end{array}$ \\
\hline & $\begin{array}{c}\text { Естетичні якості елементів } \\
\text { планувальної структури }\end{array}$ & $\begin{array}{c}\text { Площі } \\
\text { Галявини } \\
\text { Планування дорожньо-стежкової мережі } \\
\text { Візерунок мощення }\end{array}$ \\
\hline & $\begin{array}{c}\text { Просторові } \\
\text { характеристики }\end{array}$ & $\begin{array}{c}\text { Панорама } \\
\text { Перспектива } \\
\text { Багатоплановість } \\
\text { Візуальні зв'язки }\end{array}$ \\
\hline & Колорит & Різнобарвно, зелено, сіро \\
\hline \multirow{3}{*}{$\begin{array}{l}\text { Базові ознаки ком- } \\
\text { форту }\end{array}$} & $\begin{array}{c}\text { Зручність пересування } \\
\text { та відпочинку }\end{array}$ & $\begin{array}{c}\text { Розв’язка дорожньо-стежкової мережі } \\
\text { Організація місць для відпочинку } \\
\text { Організація місць громадського обслуговування } \\
\text { Вказівні знаки } \\
\text { Наявність мінливих компонентів (людей, авто, тощо) }\end{array}$ \\
\hline & $\begin{array}{c}\text { Ознаки комфорту паркового } \\
\text { середовища }\end{array}$ & $\begin{array}{c}\text { Світло-темно, } \\
\text { просторо-захаращено, чисто-брудно, } \\
\text { затишно-незатишно та ін. }\end{array}$ \\
\hline & $\begin{array}{c}\text { Санітарний стан компонен- } \\
\text { тів паркового простору }\end{array}$ & $\begin{array}{c}\text { Природних компонентів (деревно-кущових груп, } \\
\text { квітників, газону) } \\
\text { Штучних компонентів (дорожньо-стежкового покриття, } \\
\text { архітектурних компонентів, елементів інженерного } \\
\text { обладнання }\end{array}$ \\
\hline
\end{tabular}

Ознаки, що характеризують «загально-емоційну» реакцію респондента на пейзаж

Гармонійно-дисгармонійно, яскраво-монотонно, атмосферно та ін.

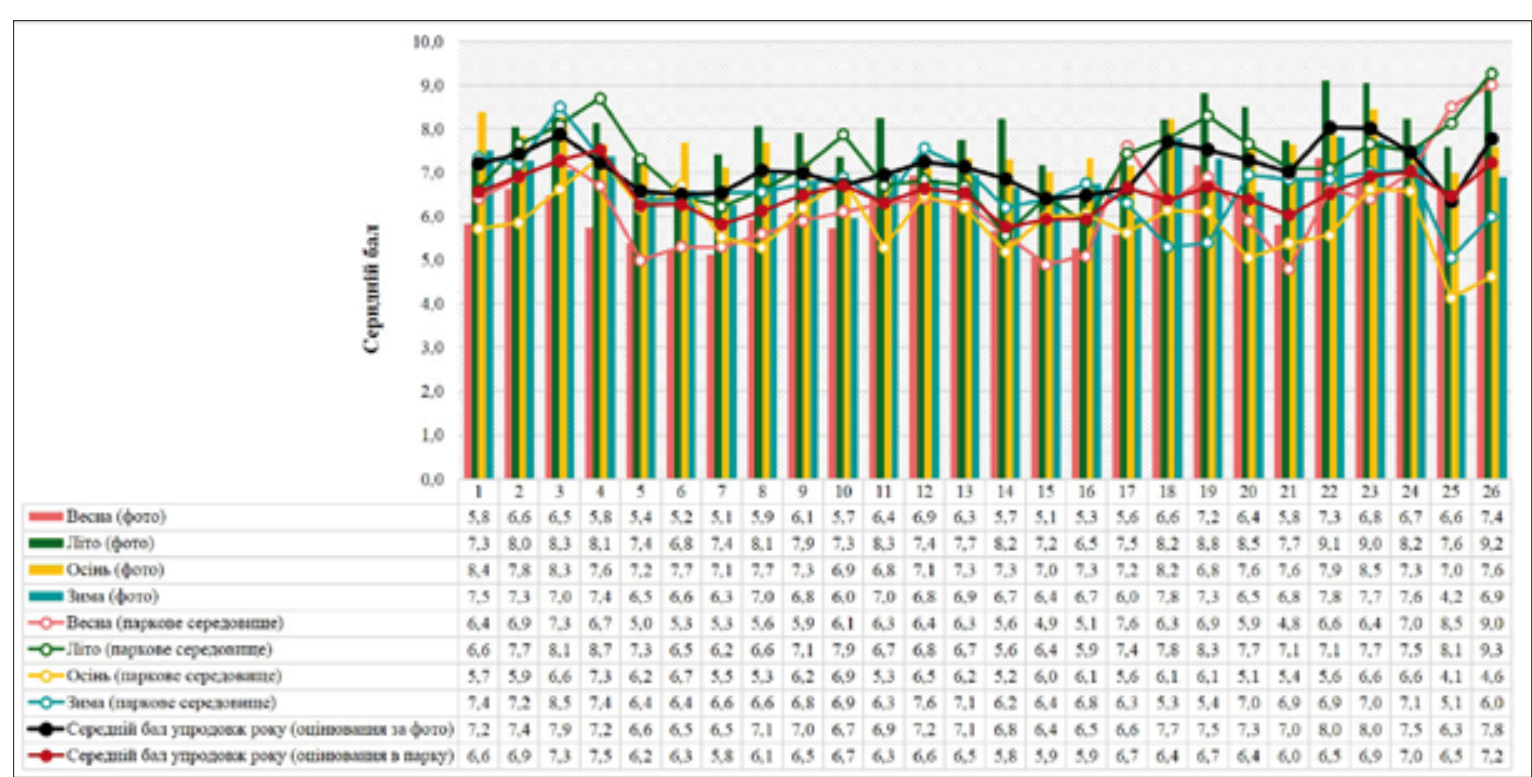

Рис. 2. Структура оцінки пейзажів Маріїнського парку упродовж року за різних способів проведення дослідження 
Наступним етапом став аналіз кореляційних зв'язків між кількістю згадувань респондентами позитивних і негативних ознак паркового середовища та середнім балом за різних сезонів та умов проведення досліджень. Відтак майже в усіх випадках, незалежно від способу дослідження, виявлено дуже сильні та сильні зв'язки (рис. 3).

Винятком $\epsilon$ зв'язок між негативними ознаками осінніх пейзажів, зауважених респондентами в парковому середовищі, та їх оцінкою, який є дуже слабким, що своєю чергою дає підстави говорити про відсутність зв'язку між частотою згадування характеристик, що мали негативний вплив на естетичну оцінку пейзажу на цей час. Помірну кореляцію виявлено між кількістю згадувань позитивних ознак зимових пейзажів, відмічених респондента- ми під час проведення оцінювання в парковому середовищі. Найтісніші зв'язки - дуже сильна як позитивна, так і негативна кореляція спостерігається під час оцінювання естетичних якостей літніх пейзажів, проведеному безпосередньо в парку.

Слабкий кореляційний зв'язок, суттєва різниця у середніх балах оцінки за умов застосування різних способів дослідження восени та помірний взимку $\epsilon$ передумовою формування гіпотези про суттєвий вплив середовища на сприйняття естетичних якостей пейзажу в осінньо-зимовий період. Водночас значна кореляція навесні та влітку може бути свідченням подібності сприйняття естетичних якостей паркового середовища за комфортних для людини умов середовища.

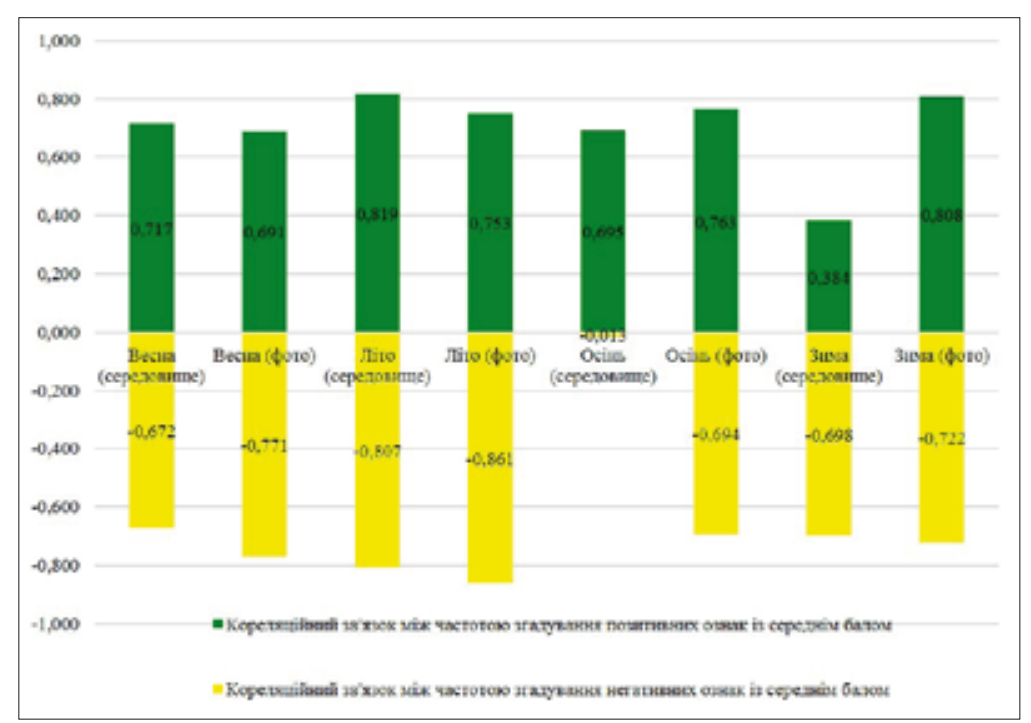

Рис. 3. Структура кореляційних зв’язків між частотою згадування позитивних і негативних ознак пейзажів Маріїнського парку із середнім балом естетичної оцінки

Наступним етапом став аналіз композиційних ознак паркового середовища, визначених респондентами 3 використанням різних способів дослідження та виявлено їх особливості. Зокрема, частота згадувань декоративності насаджень (груп, алей, солітерних посадок, архітектоніка крони тощо) та архітектурних компонентів (Маріїнського палацу, монументально-скульптурного оформлення тощо), які позитивно впливають на естетику пейзажу, відрізняється залежно від сезону та способу дослідження: за умов застосування фотографій найчастіше згадується взимку та навесні, а в середовищівлітку та восени (рис. 4).

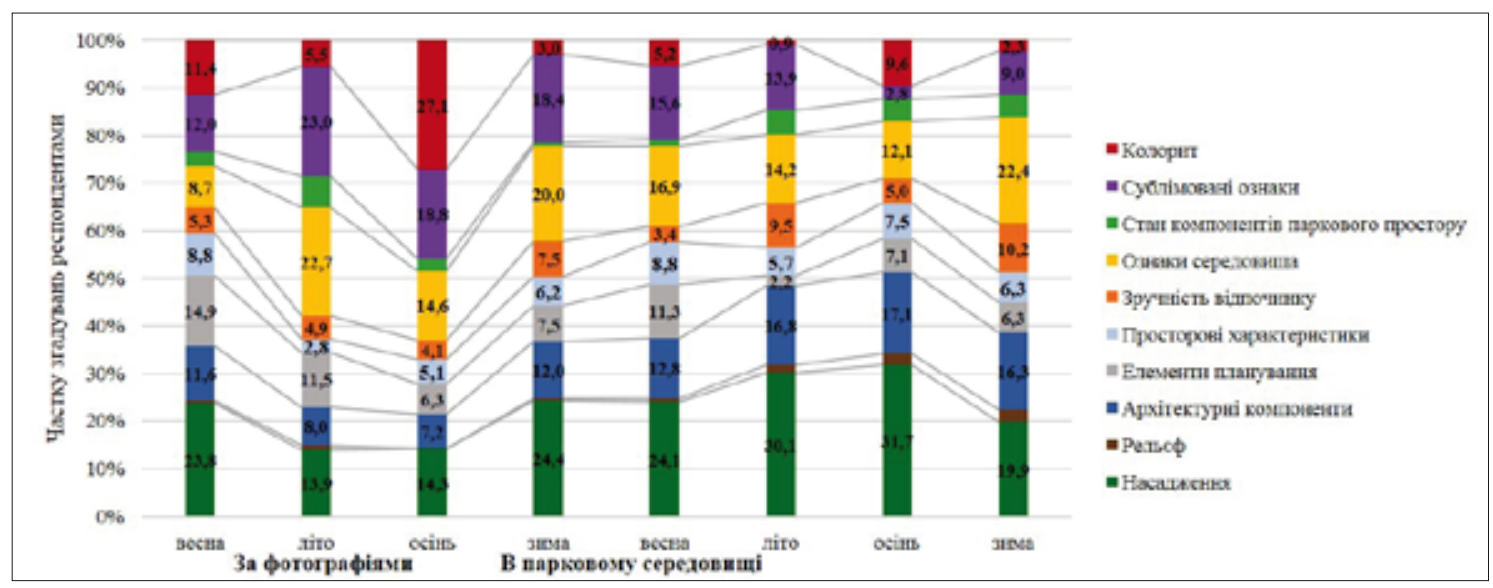

Рис. 4. Структура частоти згадувань груп ознак пейзажів Маріїнського парку як позитивних чинників їх естетичних якостей 
Окрім того, під час оцінювання в середовищі частота згадувань у межах сезону більша, ніж у разі застосування фото. Винятком є зимові пейзажі, де в середовищі декоративність насаджень відмічено респондентами дещо рідше. До пейзажів, де частка згадувань декоративності насаджень $є$ найбільшою (52,4\% респондентів зауважили), належать осінні пейзажі - 23 локації (рис. 5).

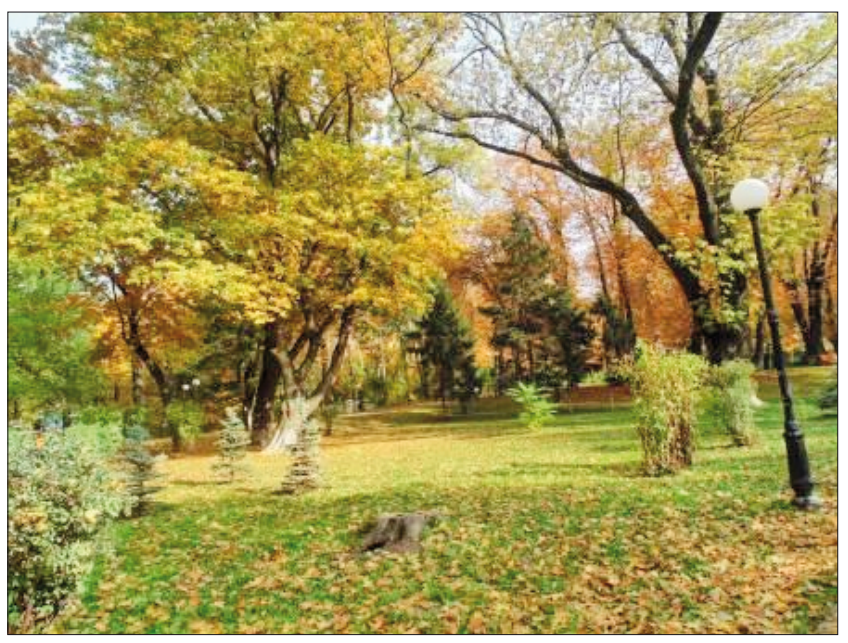

Рис. 5. Осінній пейзаж локації 23

До ознак, частота згадувань яких має найсуттєвіші відмінності, як упродовж різних сезонів, так і за умов використання різних способів дослідження, належить колорит, частка згадування якого як позитивної ознаки завжди вища в межах певного сезону під час оцінювання пейзажів за фото, ніж безпосередньо в середовищі (див. рис. 4). При цьому, найбільшу частку зауважень респондентами відмічено восени $-27,1 \%$, а кореляція між частотою згадувань краси колориту та балом естетичної оцінки на цей час $\epsilon$ значною $(0,508)$. Найбільшу частку згадувань колориту, як позитивної ознаки, відмічено в межах локації 3, фото - 3.2 (рис. 6).

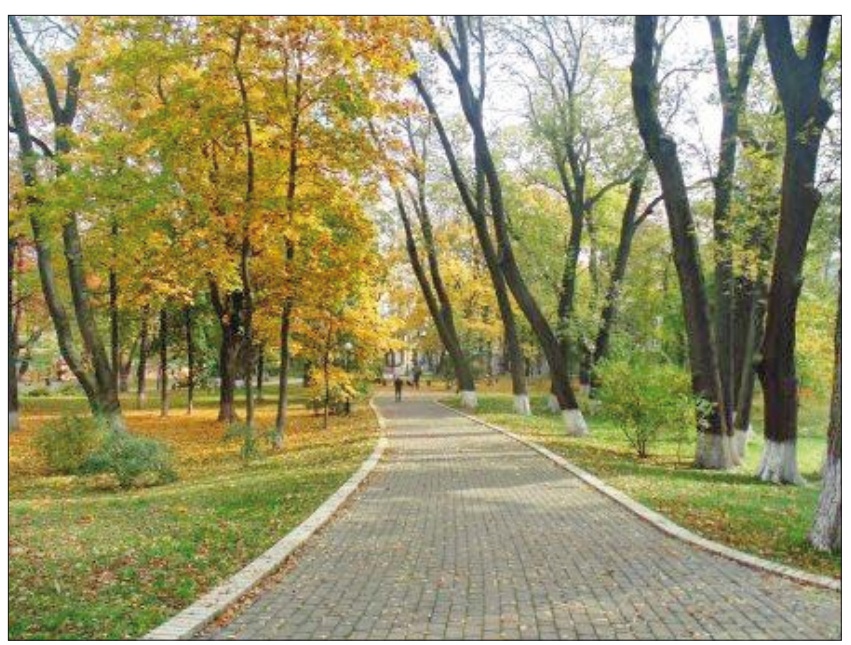

Рис. 6. Осінній пейзаж локації 3

Підсумовуючи аналіз частоти згадувань ознак та характеристик, які позитивно впливають на естетику пейзажів Маріїнського парку за різних умов прове- дення досліджень, доцільно звернути увагу на їх подібність упродовж різних сезонів за умов проведення оцінювання в середовищі та суттєві відмінності в разі застосування фото. Ці результати можуть бути свідченням подібності сприйняття паркового середовища упродовж року безпосередньо в парку. Поряд із тим, спостерігаються суттєві відмінності у частоті згадувань ряду ознак у межах кожного сезону, але за різних умов проведення досліджень.

Для підтвердження, або спростування наведених гіпотез проведено кореляційний аналіз ознак паркового середовища, визначених респондентами 3 використанням різних способів дослідження, в ході якого виявлено сильний кореляційний зв'язок між частотою згадування позитивних ознак весняних $(0,855)$ та зимових $(0,862)$ пейзажів Маріїнського парку, значний $(0,511)$ - літніх та слабкий $(0,268)$ - осінніх. Порівнюючи результати із даними літературних джерел (Stamps, 1990), варто відзначити узгодженість із даними, які отримали ми у весняний, літній та зимовий періоди, а також відмінність від результатів, що були за не комфортних, осінніх умов.

Окрім того, було проведено аналіз зв'язку між перевагами респондентів, зауваженими в різні сезони, в ході якого виявлено сильний кореляційний зв'язок між позитивними якостями, зазначеними безпосередньо в середовищі між пейзажами упродовж року - від 0,7 (між осінніми та зимовими) до 0,843 (між зимовими та літніми) (рис. 7).

При цьому, кореляція з аналогічними даними, отриманими внаслідок аналізу фотографій, менша та залежить від сезонів, які аналізуються. Цікавою $\epsilon$ найтісніша кореляція між позитивними ознаками, зауваженими респондентами у зимовий та літній періоди за обох способів проведення досліджень (див. рис. 7). При цьому кореляція між бальною оцінкою естетичних якостей пейзажів $є$ значно слабшою $-0,455$ в разі застосування фото та $-0,083$ за умов проведення оцінювання безпосередньо в парковому середовищі.

Продовжуючи аналіз взаємозв'язку бальної оцінки, наданої респондентами естетичним якостям пейзажів Маріїнського парку, доцільно зауважити на суттєвій мінливості, яка спостерігається як за умов застосування різних способів проведення дослідження, так і визначається сезонами, що порівнюються (див. рис. 7). Найтісніший зв'язок виявлено між оцінкою весняних та літніх пейзажів 0,787 в разі застосування фото та 0,718 під час оцінювання в парку. Значна кореляція спостерігається при порівнянні естетичної оцінки осінніх та зимових, також незалежно від способу проведення досліджень. Найсуттєвішу різницю у взаємозв'язку естетичної оцінки, що визначається способом досліджень, виявлено при порівнянні літніх та зимових пейзажів, де помірна $(0,455)$ кореляція наявна за умов застосування фото, а при оцінюванні в середовищі є дуже слабкою та оберненою $(-0,083)$. Такі обставини $\epsilon$ передумовою обгрунтування гіпотези, що ознаки та компоненти пейзажів Маріїнського 
парку, які позитивно впливають на їх естетичну привабливість подібні упродовж року, а найтіснішим цей зв'язок є при сприйнятті пейзажів безпосередньо в парковому середовищі.

Суттєва різниця в кореляції між бальною оцінкою естетики пейзажів є передумовою аналізу кореляційного зв'язку між частотою негативних ознак паркового середовища, що можуть на неї впливати. Результати аналізу негативних факторів суттєво відрізняються - різниця у частоті згадувань є найбільшою в характеристиці ознак середовища за умов проведення оцінювання в парку восени (рис. 8) i пов'язані, здебільшого, з погодними умовами та мікрокліматичними особливостями.

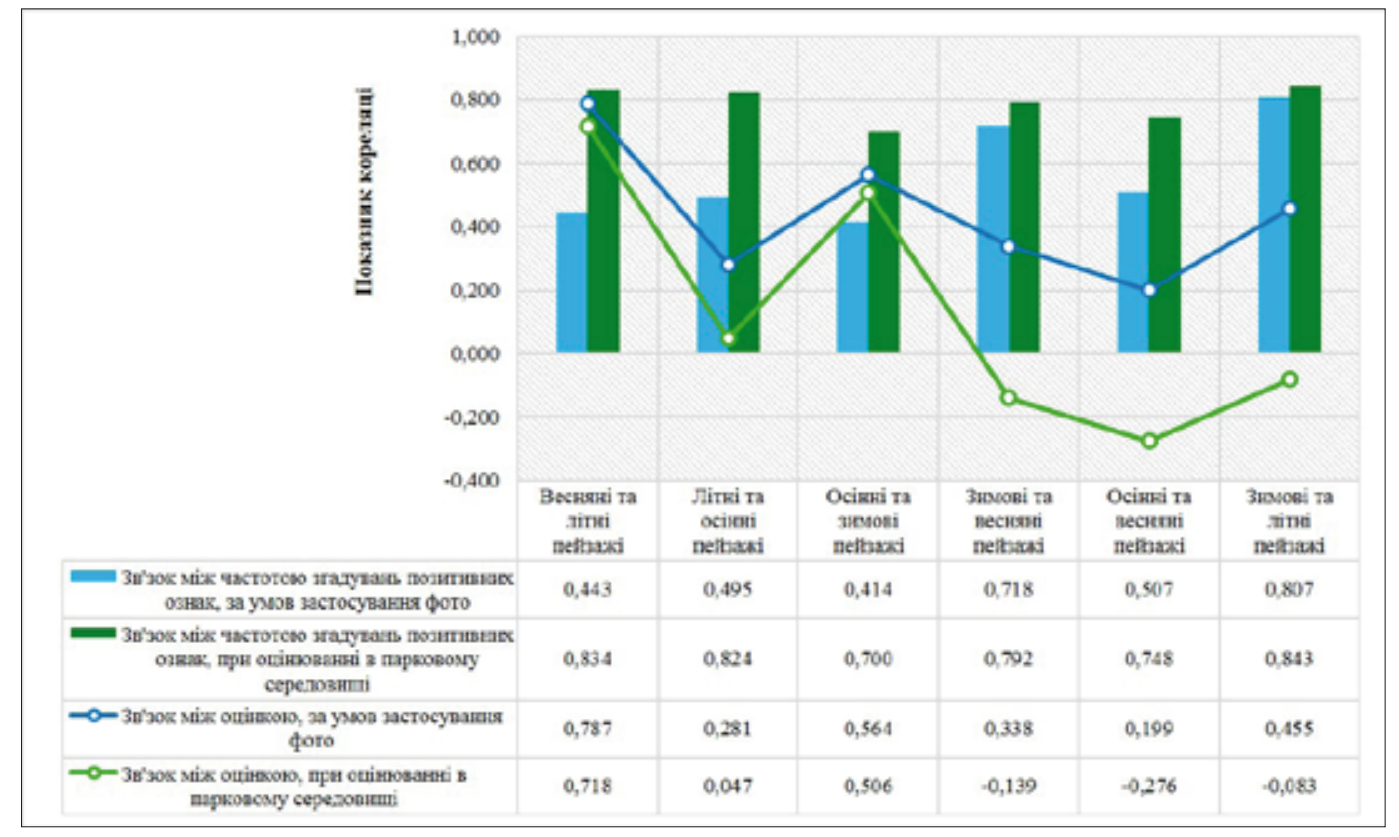

Рис. 7. Структура зв’язку між перевагами респондентів, зауваженими в різні сезони та за різних умов проведення дослідження, а також між балами естетичної оцінки пейзажів Маріїнського парку

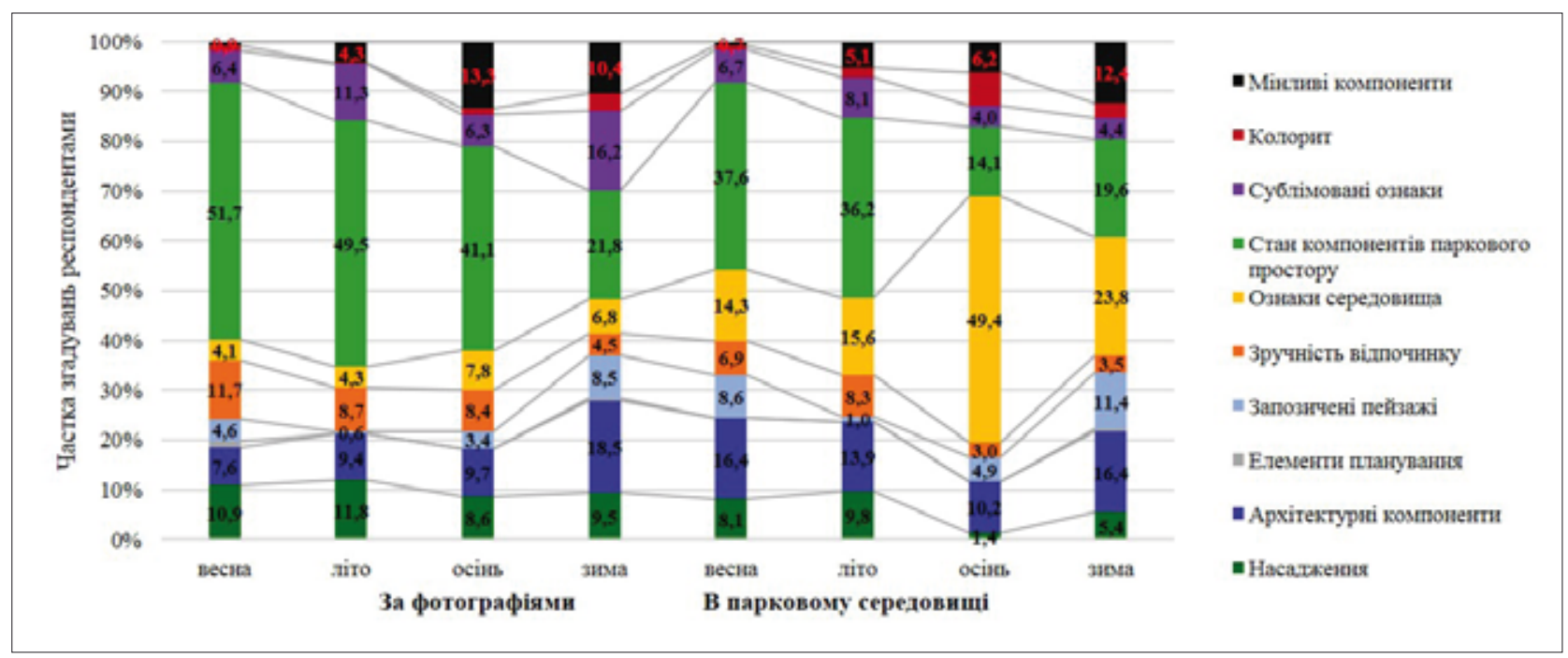

Рис. 8. Структура частоти згадувань груп ознак пейзажів Маріїнського парку як негативних чинників їх естетичних якостей

Загалом частка згадувань, пов'язаних із негативними ознаками середовища, становить 49,4\% від загальної кількості згадувань негативних ознак та характеристик паркового середовища респондентами в цей період та відмічалися респондентами як «вітряно», «холодно», «мокро» та ін. Поряд із тим, саме в цей час найменшою є частота згадувань незадовільного стану компонентів паркового серед- овища порівняно з іншими умовами та способами проведення дослідження (див. рис. 8). У цьому контексті доцільно зазначити, що частота згадувань негативних ознак середовища $є$ більшою за умов проведення досліджень в парковому середовищі порівняно із результатами, отриманими за умов застосування фото в межах кожного із сезонів. Натомість незадовільний стан компонентів паркового 
простору відмічено респондентами частіше в разі оцінювання фото, а найсуттєвішою різниця є в разі оцінювання осінніх пейзажів.

До найсуттєвіших негативних якісних характеристик паркового середовища дослідного об'єкта респондентами віднесено стан компонентів паркового простору, частка згадувань яких найбільшою $є$ при оцінюванні фото та навесні сягає максиму $51,7 \%$ від всіх негативних ознак та якостей. При цьому згадки про гарний стан компонентів теритоpiї Маріїнського мають поодинокий характер $(0,7-$ 6,6\% респондентів) упродовж року незалежно від способу проведення досліджень.

Продовжуючи аналіз частоти згадування негативних ознак паркового середовища дослідного об'єкта, потрібно зауважити на зв'язку незадовільного стану компонентів паркової території та ознак середовища. Зокрема, сумарна частка зазначених ознак залежно від сезону та способу дослідження змінюється в межах 43,4-63,5\%, а кореляційних 3в'язок між частотою їх згадувань є сильним $(-0,755)$. Сильна обернена кореляція між частотою згадувань негативних ознак паркового середовища дослідного об'єкта та незадовільного стану компонентів його території може бути свідченням зменшення уваги до незадовільного стану компонентів пейзажів за умов відсутності комфорту під час оцінювання їх естетичних якостей. Такі обставини зумовлюють формування гіпотези про доцільність застосування фотографій для оцінювання задоволеності відвідувачів парку станом його компонентів, або проведення досліджень в парку за комфортних для людини умов (весняно-літній період).

Підсумовуючи аналіз частоти згадувань ознак та характеристик, які негативно впливають на естетику пейзажів Маріїнського парку за різних умов проведення досліджень, доцільно звернути увагу на подібність їх упродовж різних сезонів та суттєві відмінності, що визначаються способом проведення. Ці результати можуть бути свідченням подібності сприйняття негативних ознак та якостей паркового середовища упродовж року безпосередньо в парку та залежать від способу проведення досліджень, що може бути свідченням впливу умов навколишнього середовища та мультисенсорності сприйняття паркового середовища на якому наголошують окремі автори (Gungor \& Polat, 2018, Osychenko, 2015).

Наступним етапом став кореляційний аналіз негативних ознак паркового середовища, визначених респондентами 3 використанням різних способів дослідження, в ході якого виявлено дуже сильний кореляційний зв'язок між частотою згадування позитивних ознак весняних $(0,907)$ та літніх $(0,929)$ пейзажів Маріїнського парку, значний $(0,537)$ - зимових та слабкий $(0,156)$ - осінніх. Окрім того, було проведено аналіз зв'язку між частотою згадувань негативних ознак, зауважених респондентами в різні сезони, в ході якого виявлено суттєві відмінності у кореляційних зв'язках між негативними якостями, зазначеними безпосередньо в середовищі між пейзажами упродовж року - від 0,355 (між осінніми та весняними) до (0,956 між весняними та літніми). При цьому кореляція з аналогічними даними, отриманими внаслідок аналізу фотографій, значно сильніша (рис. 9). Відтак дуже сильна кореляція спостерігається між весняними та літніми $(0,983)$, літніми та осінніми $(0,958)$, осінніми та весняними $(0,939)$ пейзажами, а також сильна - між осінніми та зимовими $(0,723)$, зимовими та весняними $(0,645)$, а також зимовими та літніми пейзажами $(0,736)$.

Звертаючи увагу, поряд із кореляцію між частотою згадування негативних ознак, на зв'язок між балами естетичної оцінки, наданої респондентами за різних умов та способів проведення досліджень, потрібно наголосити на подібності сприйняття весняних і літніх пейзажів, а також осінніх і зимових, адже саме в цих випадках виявлено найсильнішу кореляцію (див. рис. 9) між оцінками та негативними ознаками незалежно від способу проведення досліджень.

Деталізуючи аналіз впливу частоти згадувань ознак паркового середовища, доцільно зосередити увагу на ознаки паркових пейзажів, які характеризують суб'єктивну позитивну психоемоційну реакцію респондентів (гармонійно, приємно, атмосферно, велично тощо). Саме частота згадування зазначених характеристик можуть бути показниками естетичних якостей пейзажів, адже серед всіх ознак та характеристик найтісніші кореляційні зв'язки виявлено саме між цими позитивними ознаками та оцінкою пейзажів. Зокрема, внаслідок кореляційного аналізу виявлено найсильніші кореляційні зв'язки між частотою згадувань позитивних ознак, що характеризують суб'єктивну позитивну психоемоційну реакцію респондентів на пейзаж при оцінюванні за фото (виняток становлять весняні пейзажі). За умов проведення дослідження безпосередньо в парку кореляція - дещо слабша та коливається від помірної (осінні пейзажі) до значної (весняні, літні та зимові пейзажі (рис. 10). Кореляція між негативними ознаками та середнім балом суттєво слабша (здебільшого є слабкою), але тенденція тісніших зв'язків під час оцінювання за фото зберігається. Винятком є результати оцінювання весняних пейзажів безпосередньо в парковому середовищі, де обернена кореляція перебуває на рівні -0,586. Найслабшим є зв'язок між ознаками, що характеризують суб'єктивну психоемоційну реакцію респондентів на пейзаж (як позитивними, так і негативними) та оцінкою восени за умов оцінювання безпосередньо в парковому середовищі (див. рис. 10), що може бути свідченням впливу інших ознак на формування суб' єктивної загальноландшафтної емоційної реакції в цей період.

Серед негативних ознак, які мають найсуттєвіший вплив на сприйняття естетичних якостей пейзажів Маріїнського парку, є «базові ознаки комфорту рекреації» (див. рис. 10), що підтверджує результати дослідження Osychenko (2014), яка під час дослідження естетики міського середовища виявила сильну кореляцію між його базовими властивостями та естетичною оцінкою. 


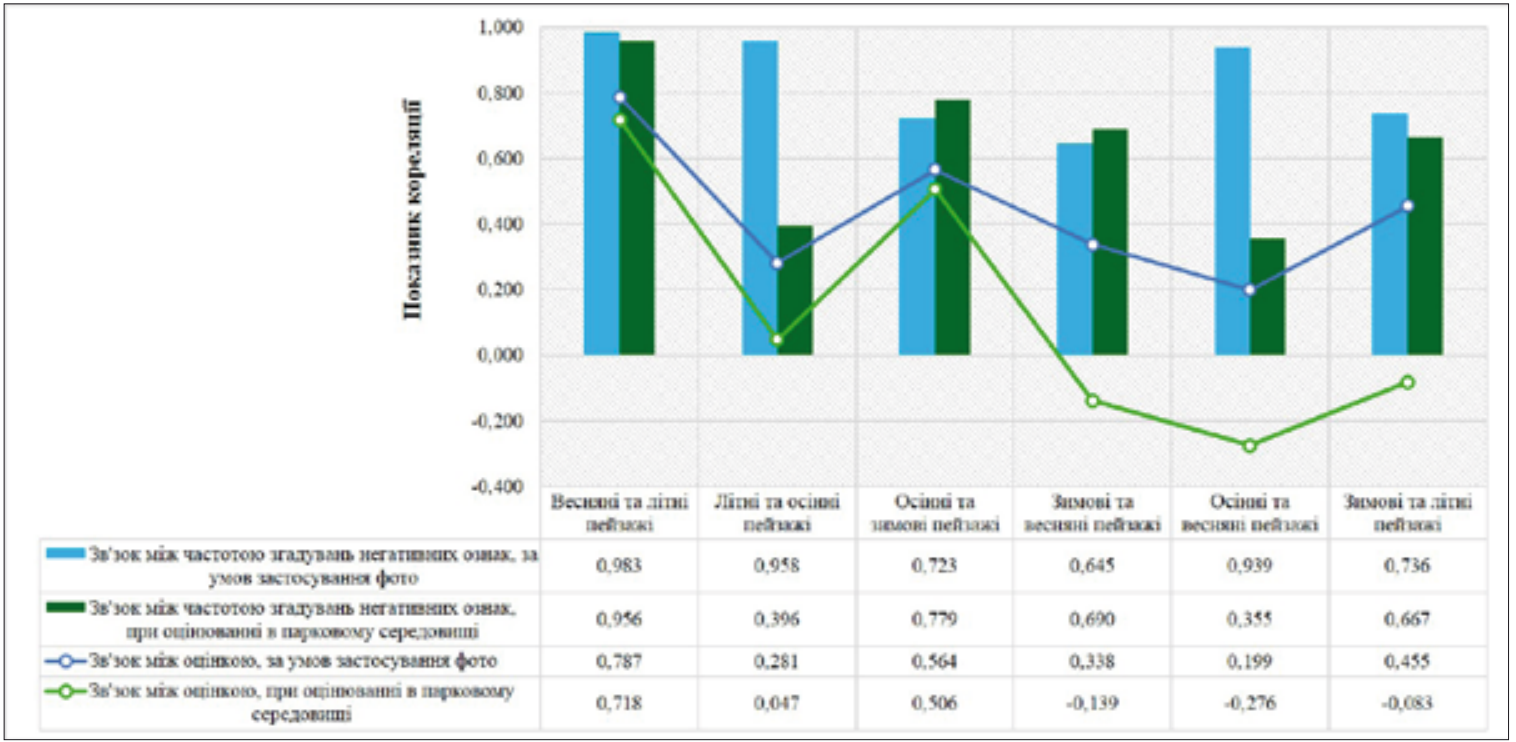

Рис. 9. Структура зв’язку між негативними ознаками, зауваженими в різні сезони та за різних умов проведення дослідження, а також між балами естетичної оцінки пейзажів Маріїнського парку

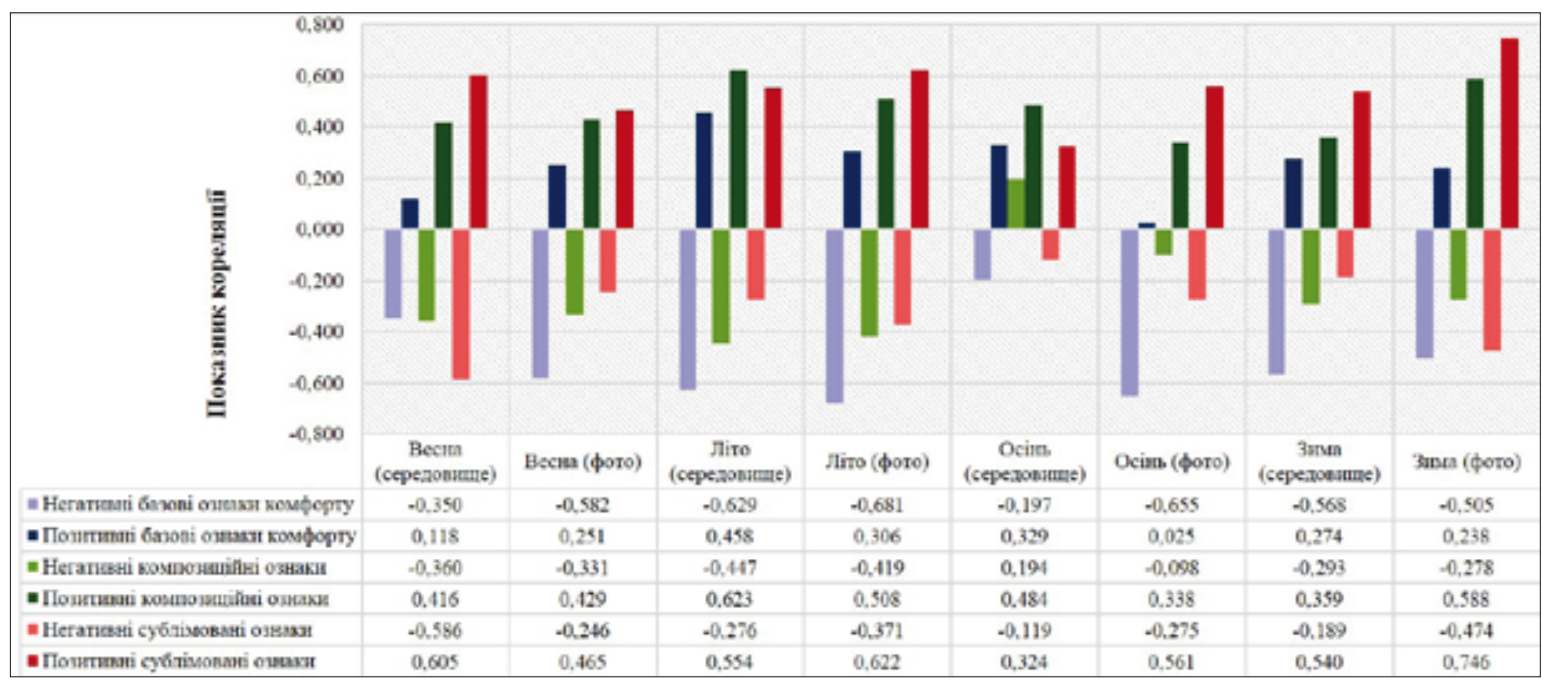

Рис. 10. Структура кореляційних зв’язків між частотою згадувань категорій ознак та характеристик паркового середовища в межах різних груп із середнім балом

Водночас вплив позитивних ознак комфорту рекреації дещо менший (слабкий навесні та взимку, помірний - влітку) та не має суттєвих відмінностей відповідно до способу проведення досліджень (див. рис. 10). Виняток - осінні пейзажі, де спостерігається суттєва різниця залежно від способу проведення дослідження - в середовищі кореляція помірна $(0,325)$, а за умов використання фото - дуже слабка $(0,025)$.

Вплив композиційної групи ознак на естетичну оцінку має суттєві відмінності. Відтак, найтісніші зв'язки (сильна кореляція) спостерігаються влітку незалежно від способу проведення досліджень. В той же час, в більшості випадків позитивна кореляція є помірною. Виключення - зимові пейзажі, за умов оцінювання за фото, де пряма кореляція $\epsilon$ значною та весняні в середовищі, де кореляційний зв'язок - слабкий.
Порівнюючи позитивний вплив композиційних ознак на естетичне сприйняття паркових пейзажів із сублімованими, треба зауважити на їх тотожності в літній період незалежно від способу проведення досліджень, восени за умов проведення дослідження в середовищі та навесні при застосуванні фото. Поряд із тим, взимку вплив композиційних ознак дещо менший ніж сублімованих. Звертаючи увагу на негативні композиційні ознаки паркового середовища, потрібно зауважити на суттєво меншому їх негативному впливі порівняно із позитивним впливом ознак композиційної узгодженості. Зокрема, значний негативний вплив спостерігається лише влітку незалежно від умов проведення досліджень та навесні під час аналізу фото. У решті випадків композиційна недосконалість компонентів паркового простору суттєвого впливу на естетичну оцінку паркових пейзажів не мала. 
Висновки. Для визначення взаємозв'язку результатів оцінювання естетики паркового середовища за різних способів дослідження знайдено кореляційні зв'язки між балами, які були надані респондентами пейзажам за фотографіями та безпосередньо на території Маріїнського парку. Суттєву різницю упродовж різних сезонів підтверджує значний кореляційний зв'язок між середнім балом фотографій і локацій у середовищі у весняний та літній періоди $(0,677$ та 0,539 відповідно), помірний $(0,366)$ - навесні та слабкий $(0,159)$ - восени.

Декоративність рослинних угруповань та архітектурних компонентів має неоднозначний характер частка згадувань як позитивних, так і негативних якостей наведених компонентів $€$ досить значною упродовж всіх сезонів та визначається способом проведення досліджень. Зокрема, найбільшою частка позитивних якостей насаджень $€$ під час оцінювання осінніх пейзажів безпосередньо в парку, при цьому лише 1,4\% від всіх негативних зауважень стосуються незадовільної композиції та декоративності насаджень у цей період. Подібну ситуацію встановлено і стосовно архітектурних компонентів, але різниця у частоті згадувань, як позитивних, так і негативних декоративних якостей, відповідно до способу проведення досліджень $є$ меншою. До ознак, частота згадувань яких має найсуттєвіші відмінності, як упродовж різних сезонів, так і за умов використання різних способів дослідження, належить колорит, особливості якого в пейзажах Маріїнського парку сприймаються респондентами позитивно (частка негативних ознак колориту $є$ незначною), найчастіше відмічаються при оцінюванні фотографій, а найчастіше позитивні якості колориту відмічено восени.

До ознак, вплив яких на естетичну оцінку паркових пейзажів суттєво відрізняється відповідно до способу проведення досліджень та сезону, відносять ознаки, що характеризують суб'єктивну психоемоційну реакцію респондентів на пейзаж (яскраво-монотонно, гармонійно-дисгармонійно, цікаво-нецікаво, атмосферно тощо), а найсуттєвіший вплив спостерігається за умов застосування фото, що обумовлює доцільність застосування фотографій для визначення психоемоційного впливу паркового середовища на відвідувачів, а також сприйняття його образно-символічної структури.

Позитивні ознаки, зауважені респондентами внаслідок суб'єктивного сприйняття пейзажів, здійснюють найсильніший, порівняно 3 іншими ознаками та характеристиками, позитивний вплив на формування естетичної оцінки паркового середовища (кореляція між частотою їх згадувань та оцінкою в різні сезони змінюється в межах 0,3240746). Однак негативні сублімовані ознаки значно менше пов'язані із погіршенням оцінки естетичних якостей пейзажів.

Для оцінювання задоволеності відвідувачів парку станом його компонентів доцільним є застосування фотографій, або проведення досліджень у парку за комфортних для людини умов (веснянолітній період), адже виявлено взаємозв'язок частоти згадувань негативних ознак паркового середовища, пов'язаних із комфортом та станом його компонентів - із збільшенням першого показника - зменшується другий і навпаки, що підтверджено сильним оберненим $(-0,755)$ кореляційним зв'язком. При цьому взаємовплив позитивних якостей наведених ознак є слабким $(0,180)$.

\section{Бібліографічні посилання}

Daniel, T. C., \& Boster, R. S. (1976). Measuring landscape esthetics: the scenic beauty estimation method. In: USDA Forest Service Research Paper, RM-167. Rocky Mountain Forest and Range Experiment Station, Fort Collins, Colo. 66 p.

Dramstad, W. E., Tveit, M. S., Fjellstad, W. J., \& Fry, G. L. A. (2006). Relationships between visual landscape preferences and map-based indicators of landscape structure. Landscape and Urban Planning 78(4), 465-474.

Gungor, S., \& Polat, A. T. (2018). Relationship between visual quality and landscape characteristics in urban parks. Journal of Environmental Protection and Ecology 19 (2), 939-948.

Farahani L. M., \& Maller C. (2018) Perception and Preferences of Urban Greenspaces: A Literature Review and Framework for Policy and Practice. Landscape Online, 2, (1-22). https://doi.org/10.3097/ LO.201861

Hofmann, M., Westermann, J.R., Kowarik, I., \& van der Meer E. (2012). Perceptions of parks and urban derelict land by landscape planners and residents. Urban Forestry \& Urban Greening, 11 (3), 303-312.

Kabisch, N., Qureshi, S., \& Haase, D. (2015). Humanenvironment interactions in urban green spaces A systematic review of contemporary issues and prospects for future research. Environmental Impact Assessment Review, 50, 25-34. https://doi. org/10.1016/j.eiar.2014.08.007

Kaplan, R. \& Kaplan, S. (1989). The Experience of Nature. Cambridge: Cambridge University Press.

Lin, B. B., Fuller, R. A., Bush, R., Gaston, K. J., \& Shanahan, D. F. (2014). Opportunity or Orientation? Who Uses Urban Parks and Why. Plos One, 9 (1). https://doi.org/10.1371/journal.pone.0087422

Osychenko, G.O. (2014). Classification of the aesthetic qualities of the urban environment. New University, 3-4, 28-34 (in Ukrainian).

Osychenko, G. (2015). Methodological basis for the formation of the urban environment aesthetics. (Doctoral dissertation). Retrieved from Proquest Digital Dissertations. (739565). (in Ukrainian).

Polat, A. T., \& Akay, A. (2015). Relationships between the visual preferences of urban recreation area users and various landscape design elements. Urban Forestry \& Urban Greening, 14 (3), 573-582. https:// doi.org/10.1016/j.ufug.2015.05.009 
Stamps A.E. (1990). Use of photographs to simulate environments - a meta-analysis. Perceptual and Motor Skills, 71 (3), 907-913.

Thorpert, P., \& Nielsen, A. B. (2014). Experience of vegetation-borne colours. Journal of Landscape Architecture, 9 (1), 60-69. https://doi.org/10.1080/1 8626033.2014 .898834

Yilmaz S., Özgüner H., \& Mumcu S. (2018) An aesthetic approach to planting design in urban parks and greenspaces. Landscape Research, 43(7), 965983. doi.org/10.1080/01426397.2017.1415313

Zube E. H., Sell J. L., Taylor J. G. (1982). Landscape perception - research, application and theory. Landscape Planning, 9 (1), 1-33.

\section{Особенности влияния среды на оценку эстетических качеств парковых пейзажей: теоретические и прикладные аспекты}

\section{Н. О. Алексейченко ${ }^{1}$, Н. В. Гатальская²}

Представлен спектр исследований эстетического оценивания ландшафта с привлечением респондентов (42 человека), которые проводились в течение 2017-2018 гг. непосредственно в парковой среде, а также с применением фотографий. При использовании различных методологических подходов и по результатам сравнительного анализа особенностей восприятия пейзажей парковой среды выявлены взаимосвязи между эстетической оценкой паркового ландшафта и признаками, которые влияют на ее формирование.

По результатам обобщений теоретических и практических научных работ обнаружена принципиальная разница в методологии исследований эстетики парковых ландшафтов с привлечением респондентов. В частности, ключевым методологическим вопросом исследования эстетики парковой среды является определение способа проведения исследований - натурный, или замещения.

Выявлено, что в условиях оценки парковой среды непосредственно в парке оценка, как правило, снижается в сравнении с фотографиями. По результатам анализа частоты упоминаний признаков и характеристик, которые положительно влияют

\footnotetext{
Алексейченко Надежда Александровна - академик Лесной академии наук Украины, доктор сельскохозяйственных наук, профессор кафедры ландшафтной архитектуры и фитодизайна. Национальный университет биоресурсов и природопользования Украины, ул. Генерала Родимцева, 19, г. Киев, 03041 , Украина. Тел.: 044-227-82-96, +38-098-330-22-78. E-mail: nadiaolex@ukr.net

Гатальская Надежда Викторовна - кандидат сельскохозяйственных наук, доцент кафедры ландшафтной архитектуры и фитодизайна. Национальный университет биоресурсов и природопользования Украины, ул. Генерала Родимцева, 19, г. Киев, 03041, Украина. Тел.: 044-227-82-96, +38-067-728-6920. E-mail: gatalska@ukr.net
}

на эстетику пейзажей Мариинского парка, определено их сходство в течение разных сезонов в условиях проведения оценки в непосредственно парке и существенные различия при применении фото. Данные результаты могут быть свидетельством сходства восприятия парковой среды в течение года непосредственно в парке. Наряду с этим, наблюдаются существенные различия в частоте упоминаний ряда признаков в пределах каждого сезона при условии применения различных способов исследований.

Несмотря на существенную разницу в частоте упоминаний признаков парковой среды при различных условиях и способах проведения исследований установлено, что сила воздействия конкретного признака на эстетические качества пейзажей не определяет ее факторный вес в оценке, однако связана с ней. Наряду с тем, выявлены признаки, влияние которых на эстетическую оценку парковой среды является существенным.

Выяснено, что применение фотографий целесообразно для определения восприятия колорита и образно-символической структуры пейзажей парковой среды посетителями, а оценивание влияния насаждений и архитектурных компонентов на эстетические качества пейзажей целесообразнее проводить непосредственно в парке. Оценку удовлетворенности посетителей парка состоянием его компонентов можно осуществлять используя фотографии или проводя исследования в парке при условии комфортных для человека (весенне-летний период) условий.

Ключевые слова: восприятие парковых пейзажей; методология оценки ландшафта; сезонная динамика; корреляционный анализ.

\section{Features of the influence of the environment on the estimation of aesthetic qualities of park landscapes: theoretical and applied aspects}

\author{
N. Oleksiichenko', N. Gatalska²
}

The article presents a spectrum of aesthetic assessment of the landscape with the involvement of respondents (42 people) that were conducted during 2017-2018 directly in the park environment and

\footnotetext{
Nadiia Oleksiichenko - full Member of the Forest Academy of Sciences of Ukraine, Doctor of Agricultural Sciences, Professor of the Department of Landscape Architecture and Phytodesign of National University of Life and Environmental Sciences of Ukraine. General Rodimtsev st., 19, Kyiv, 03041, Ukraine. Tel.: 044-227-82-96, +38-098-330-22-78. E-mail: nadiaolex@ukr.net

2 Nadiia Gatalska-Ph.D. in Agricultural Sciences, Associate Professor of the Department of Landscape Architecture and Phytodesign of National University of Life and Environmental Sciences of Ukraine. General Rodimtsev st., 19, Kyiv, 03041, Ukraine. Tel .:044-227-8296, +38-067-728-69-20. E-mail: gatalska@ukr.net
} 
with the use of photographs. Taking into account the various methodological approaches and the results of the comparative analysis of the peculiarities of the perception of landscapes of the park environment, interrelation between the aesthetic assessment of the park landscape and the features that influence its formation are revealed.

As a result of generalizations of theoretical and practical scientific works, a fundamental difference in the methodology of research on the aesthetics of park landscapes with the involvement of respondents was found. The key methodological issue of studying the aesthetics of the park environment is the determination of the method of conducting research - full or replacement.

It is revealed that in the conditions of evaluation of the park environment evaluation directly in the park, the rating is reduced in comparison with the photographs. By analyzing the frequency of references to features and characteristics that have a positive effect on the aesthetics of the Mariinsky Park landscapes, their similarity has been determined throughout the various seasons under the conditions of evaluation in the environment and significant differences in the application of the photo. These results can be evidence of a similar perception of the park environment throughout the year directly in the park. At the same time, there are significant differences in the frequency of references to a number of signs within the limits of each season under the conditions of different methods of research. Despite the significant difference in the frequency of references to the signs of the park environment under different conditions and methods of conducting research, it has been established that the force of influence of a specific feature on the aesthetic qualities of landscapes does not determine its factor weight in the evaluation, but is related to it. In addition, signs have been identified, whose impact on aesthetic assessment of the park environment is significant.

It is determined that the use of photographs is appropriate for determining the perception of the color and figurative and symbolic structure of the landscape landscape of visitors, and assessing the impact of plantations and architectural components on the aesthetic qualities of landscapes should be carried out directly in the park. Estimation of the satisfaction of visitors to the park as its components can be carried out with the use of photographs or holding or in the park in a comfortable environment for the person (spring-summer period).

Key words: park landscape perception; landscape assessment methodology; seasonal dynamics; correlation analysis. 